\title{
GENERAL SURVEY OF FODDER TREES AND SHRUBS OF BIRATNAGAR AND SURROUNDING LOCALITY
}

\author{
Min Raj Dhakal \\ Abdul Aziz

\section{INTRODUCTION} \\ Growing urbanization in Biratnagar has greatly increased the demand for \\ livestock products (chiefly, milk and meat) but has an opposite effect on livestock \\ population. Livestock population is decreasing even in the surrounding villages largely \\ due to the lack of good pasture. Still there are a few households inside the town and \\ some farmers on the surrounding locality who kept a small number of cows and \\ buffaloes. But the supply of green fodders to these animals is poor and the animals are \\ living in a measurable condition (Aziz; 1981).
}

Fodder trees and shrubs from the different forest of the hills surrounding Kathmandu valley has been studied (Shrestha, 1978; Dhakal, 1979) and analysed for their chemical contents. But no such work is ever done in Biratnagar. The fodder from the terai region still await a detailed exploration. In the present work an attempt is made to catalogue the fodder trees and shrubs of Biratnagar and nearby villages and to collect farmers' information about the fodder plants.

\section{MATERIALS AND METHODS}

Fodder plants were selected on the basis of local farmers information. Information was collected by preparing a questionnaire. Following standard technique (Lawrence; 1974) herbarium sheets were prepared and the plants were identified for their botanical names by Botany Instruction committee, Mahendra Morang Campus, Biratnagar and the herbarium section of the Department of Botany, in the Botanical Garden, Godavari. The Herbaria are deposited in the Department of Botany, Mahendra
Morang Campus, Biratnagar.

\section{RESULTS}

Table no. 1 gives a list of 33 plants from BiratNagar and nearby villages which are usually used to feed the cattle and the goats. About $50 \%$ of the plants collected belong the two families. Moraceae (8 Species) and Leguminosae (8 Species). Rest are distributed among other different families. Local farmers' information on different aspects of the fodder are summarized on table 2 . Among the collected species majority 


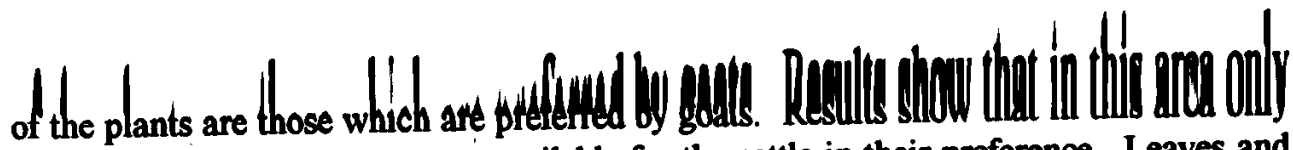
a few species of fodder trees are available for the cattle in their preference. Leaves and some times the young twigs are the parts taken by the animals, although goats sometimes browse on the barks. On farmers' judgment again the majority of the tree plants which are considered as good fodder are from the families Leguminosae and Moracae.

Table I: List of the fodder plants from Biratnagar

\begin{tabular}{|c|l|l|l|}
\hline S.No. & \multicolumn{1}{|c|}{ Name of the Plants } & \multicolumn{1}{|c|}{ Family } & Local Name \\
\hline 1. & $\begin{array}{l}\text { Acacia nilotica (L) wild ex delile ssp. } \\
\text { indica Slow growing and spreading, } \\
\text { medium sized tree }\end{array}$ & Leguminoasae & Babul \\
\hline 2. & $\begin{array}{l}\text { Aegle marmelos (Benth) Brenam Tall } \\
\text { Tree }\end{array}$ & Rutaceae & Bel \\
\hline 3. & $\begin{array}{l}\text { Albizia julibrissin Durranzz Much } \\
\text { spreading, fast growing tree }\end{array}$ & Leguminosae & Rato Siris \\
\hline 4. & A. Procera Benth & Leguminosae & Seto Siris \\
\hline 5. & $\begin{array}{l}\text { Anacardium occidentale L Medium } \\
\text { sized, slow growing tree }\end{array}$ & Anacardiaceae & Dante Okhar \\
\hline 6. & $\begin{array}{l}\text { Anthocephalus chinensis (Lamk) A. } \\
\text { Rich ex Walp. Slow growing, Tall tree }\end{array}$ & Rubiaceae & Kadam \\
\hline 7. & $\begin{array}{l}\text { Annona squmosa (L) Small, much } \\
\text { spreading shrub }\end{array}$ & Anonaceae & Sarifa \\
\hline 8. & $\begin{array}{l}\text { Artocarpus heterophyllus Lamk Much } \\
\text { spreading, tall tree }\end{array}$ & Moraceae & Kathar \\
\hline 9. & $\begin{array}{l}\text { A lacucha Buch. Ham Slow growing, } \\
\text { non spreading tree }\end{array}$ & Moraceae & Badahar \\
\hline 10. & $\begin{array}{l}\text { Bambusa tulda Roxb Fast growing, tall } \\
\text { tree }\end{array}$ & Gramineae & Bans \\
\hline 11. & $\begin{array}{l}\text { Bauhinia purpurea L Medium sized } \\
\text { tree or shrub }\end{array}$ & Leguminosae & Tanki \\
\hline 12. & $\begin{array}{l}\text { B. variegata L Medium sized tree, } \\
\text { spreading }\end{array}$ & Leguminosae & Koiralo \\
\hline 13. & $\begin{array}{l}\text { Bombax cieba L. Fast growing, } \\
\text { muchspreading, tall tree }\end{array}$ & Bombacaceae \\
\hline 14. & $\begin{array}{l}\text { Dalbergia SissooRoxb Fast growing, } \\
\text { tall tree }\end{array}$ & Leguminosae \\
\hline 15. & $\begin{array}{l}\text { Sizygium cumini (L) Skells Slow } \\
\text { growing, spreading, tall tree }\end{array}$ & Mistaceae \\
\hline
\end{tabular}


GENERAL SURVEY OF

\begin{tabular}{|c|c|c|c|}
\hline S.Na. & Name of the Plants & Family & Local Name \\
\hline 16. & $\begin{array}{l}\text { Erythrina arborescens Roxb. Wide } \\
\text { spreading, small tree }\end{array}$ & Leguminosae & Phaledo \\
\hline 17. & $\begin{array}{l}\text { Ficus benghalensis (L) Much } \\
\text { spreading tree }\end{array}$ & Moraceae & Bar \\
\hline 18. & $\begin{array}{l}\text { F. racemosa L Medium sized, } \\
\text { spreading tree }\end{array}$ & Moraceae & Dumri \\
\hline 19. & F. religiosa L. Tall tree, spreading & Moraceae & Pipal \\
\hline 20. & $\begin{array}{l}\text { F. hisipda L.f., wide spreading, small } \\
\text { tree shrub }\end{array}$ & Moraceae & Khasreto \\
\hline 21. & $\begin{array}{l}\text { F. infectaria Roxb, much spreading, } \\
\text { tall tree }\end{array}$ & Moraceae & Kabro \\
\hline 22. & $\begin{array}{l}\text { Listsea polyantha Juss Medium sized } \\
\text { tree }\end{array}$ & Loranthaceae & Kutmiro \\
\hline 23. & $\begin{array}{l}\text { Magnifera indica L. Cultivated, wide } \\
\text { spreading fruit tree }\end{array}$ & Anacardiaceae & Anp \\
\hline 24. & $\begin{array}{l}\text { Morus australis Poir, wide spreading } \\
\text { small tree or shrub }\end{array}$ & Morceae & Kimbu \\
\hline $25_{3}$ & $\begin{array}{l}\text { Litchi chinensis Sonn Small, sprading, } \\
\text { cultivated fruit tree }\end{array}$ & Sapindaceae & Litchi \\
\hline 26. & $\begin{array}{l}\text { Psidtum guajva L. Small, spreading, } \\
\text { cultivated fruit tree }\end{array}$ & Myrtaceae & Ambak \\
\hline 27. & $\begin{array}{l}\text { Shorea robusta gaertn. F. Tall, } \\
\text { slowgrowing tree }\end{array}$ & Dipterocarpeceae & Sal \\
\hline 28. & Zizipus mauritiana Bushy Shrub & Rhamnceae & Bayar \\
\hline 29. & $\begin{array}{l}\text { Leucaena leucocephala (Lamk) De } \\
\text { Wit Bushy, shrub, fast growing tree }\end{array}$ & Leguminosae & Epil-epil \\
\hline 30. & $\begin{array}{l}\text { Syzygium jambos (L) Aisto Small, } \\
\text { spreading tree }\end{array}$ & Myrtaceae & Gulabjamun \\
\hline 31. & $\begin{array}{l}\text { PithecellobiuM dulice (Roxb) Benth } \\
\text { Small tree }\end{array}$ & Leguminceae & Jilebi \\
\hline 32. & $\begin{array}{l}\text { Vitex negundo L. Wide spreading, } \\
\text { Shrub }\end{array}$ & Verbinaceae & Simali \\
\hline 33. & Manihot utilissima Pohl. & Eurphorbiaceae & Simal tree \\
\hline
\end{tabular}

\section{DISCUSSION}

Providing Livestock with nutritious feed and fodder is necessary for maintaining them in a good condition for the economic production of milk, meat and other products. There is considerable lack of information about the fodder resources 


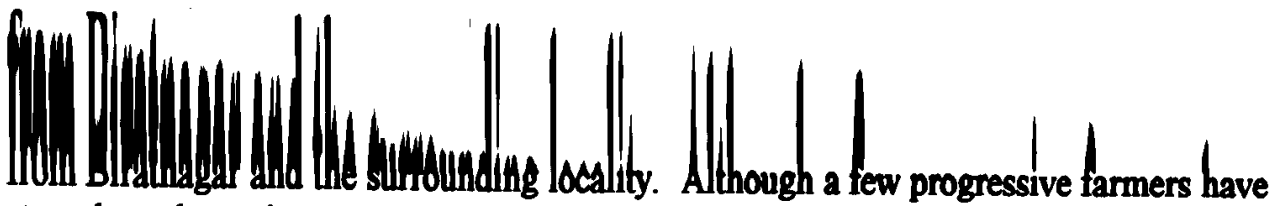
started to keep improved hybrid cows, their feeding and husbandry is still too "sophisticate" and beyond approach for the large majority of the farmers. Farmers keep the so called "local stock". The large bulk of the feed of these animals is obtained from the crop residue such as hay, straw, dry stalks of crop plants and green or dry grasses. In the lack of adequate alternative source of animals feed, green fodder, consisting of herbage and tree leaves, plays an important role in the nutrition of animals.

Table 2: Local farmers information on fodder plants from Biratnagar

\begin{tabular}{|c|l|l|l|l|}
\hline S. & \multicolumn{1}{|c|}{ Name of plant } & \multicolumn{1}{|c|}{$\begin{array}{c}\text { Season of } \\
\text { feeding }\end{array}$} & $\begin{array}{c}\text { Quality } \\
\text { of } \\
\text { fodder }\end{array}$ & $\begin{array}{c}\text { Preference by } \\
\text { the livestock } \\
\text { group }\end{array}$ \\
\hline 1. & Acacia niltica & all over the year & good & goat \\
\hline 2. & Aegle marmelos & all over the year & fair & goat \\
\hline 3. & Abizia julibrissin & spring & good & cows \& buffalo \\
\hline 4. & A. Procera & all over the year & good & goats \\
\hline 5. & Anacardium occidentale & all over the year & fair & goat \\
\hline 6. & Anthocephalus chinensis & all over the year & not good & goat \\
\hline 7. & Annona squmosa & all over the year & not good & cows/buffaloes \\
\hline 8. & Artocarpus heterophyllus & all over the year & good & cows/buffaloes \\
\hline 9. & A lacucha & all over the year & good & cows/buffaloes \\
\hline 10. & Bambusa tulda & winter & good & cows/buffaloes \\
\hline 11. & Bauhinia purpurea & winter & good & cows/buffaloes \\
\hline 12. & B. variegata & winter & good & goat \\
\hline 13. & Bombax cieba & summer & not good & goats \\
\hline 14. & Dalbergia sissoo & summer & fair & goats \\
\hline 15. & Sizygium cumini & summer & not good & goats \\
\hline 16. & Erythrina arborescens & summer & good & cows/buffaloes \\
\hline 17. & Ficus benghalensis & all over the year & good & cows/buffaloes \\
\hline 18. & F. racemosa & all over the year & good & cows/buffaloes \\
\hline 19. & F. religiosa & all over the year & good & cows/buffaloes \\
\hline 20. & F. hisipda & all over the year & good & cows/buffaloes \\
\hline 21. & F. infectaria & all over the year & good & cows/buffaloes \\
\hline 22. & Listsea polyantha & winter & fair & goats \\
\hline 23. & Magnifera indica & all over the year & fair & cows/buffaloes \\
\hline 24. & Morus australis & all over the year & good & goats \\
\hline 25. & Litchi chinensis & all over the year & fair & goats \\
\hline & & & \\
\hline
\end{tabular}


GENERAL SURVEY OF

\begin{tabular}{|c|l|l|l|l|}
\hline $\begin{array}{r}\text { S. } \\
\text { No. }\end{array}$ & \multicolumn{1}{|c|}{ Name of plant } & Season of feeding & $\begin{array}{c}\text { Quality } \\
\text { of fodder }\end{array}$ & $\begin{array}{l}\text { Preference by } \\
\text { the livestock } \\
\text { group }\end{array}$ \\
\hline 26. & Psidtum guajva & summer, autumn & not good & goats \\
\hline 27. & Shorea robusta & all over the year & fair & goats \\
\hline 28. & Zizipus mauritiana & all over the year & not good & cows/buffaloes \\
\hline 29. & Leucaena leucocephala & all over the year & good & goats \\
\hline 30. & Syzygium jambos & all over the year & fair & goats \\
\hline 31. & Pithecellobium dulce & all over the year & not good & goats \\
\hline 32. & Vitex negundo & all over the year & not good & goats \\
\hline 33. & Manihot utilissima. & summer, autumn & not good & goats \\
\hline
\end{tabular}

In Biratnagar and the nearby villages animals are fed with very low quantity of green fodder, local farmers never give their animals any concentrate and balanced diets. There is no question of supplying livestock with supplement for minerals and vitamins. Farmers lack any scientific knowledge about the fodder, livestock feeding and management. However, they have a good traditional knowledge about the fodder plants and livestock feeding, sufficient to keep animals alive and to draw minimum advantage from. theirthem, so that the farmers themselves be alive. Farmers usually prefer multipurpose trees or shrub to plant in their fields. They generally cultivate that plants However they give more prich are fast growing, of medium height and spreading habit In the town area and the priority to the quantity of the fodder rather than their quantity. on raising trees and shrubs. by plantation of fodder trees and shreholds keeping one or a few animals may be benefited the plants even in the gardens in on the periphery of the town. They can cultivate evergreen plant with suitable growth habit ornamental plants. Selection of good ornamental, fodder and as fuel wood.

The present work simply summarizes local farmers information on the quality of fodder plants. Chemical analysis of the plants will reveal necessary nutrient contents of the fodder and helps in determining their feed values in a scientific basis. Feed et.al., 1985). A few plants common in our study has shown that many of the fodders
considered good by the farmers and cultivated particularly as feed value analysed on scientific cultivated particularly as fodder have also higher Artocarpes and leguminous plants study and improvements. 


\section{WORKS CITED}

Aziz, Abdual, (1981), "Study of fodder trees and shrubs of Biratnagar," B.Sc. Dissertation, M.A. Campus, Biratnagar,

Bajracharya D, T.B. Bhattarai, M.R. Dhakal, T.N. Mandal, M.R. Sharma, S. Sitaula and B.K. Vimal, (1985), "Some feed values for fodder plants from Nepal." Angew, Botanik, 59:357-365.

Dhakal, M.R., (1979), "General survey and biochemical analysis of fodder trees found in Hatiban Hill forest", M.Sc. thesis, Tribhuvan University, Kathmandu, Nepal.

Lawrence G.H.M., (1974), Taxonomy of vascular plants, Oxford and IBM, Pub. Co., New Delhi.

Shrestha A.K., (1978), "Biochemical analysis of fodder trees of Nagarjun Hill forest". M.Sc. thesis, Tribhuvan University, Kathmandu Nepal. 